Josip Arnerić*

Luka Vladović ${ }^{* *}$
JEL klasifikacija: C23, C40, E44

Prethodno priopćenje

https://doi.org/10.32910/ep.72.2.3

\title{
MAKROEKONOMSKE DETERMINANTE DIONIČKIH CIJENA NA PRIMJERU HRVATSKE
}

Cilj je ovog rada istražiti povezanost između makroekonomskih pokazatelja hrvatskog gospodarstva i dioničkih cijena na Zagrebačkoj burzi. U tu svrhu korišteni su panel-podatci i korigirani procjenitelj fiksnog efekta. U dosadašnjim istraživanjima na ovu temu nije korišten korigirani procjenitelj fiksnog efekta, već su korišteni ostali procjenitelji statičkih panel-modela (procjenitelj s fiksnim efektom $i$ združeni procjenitelj) $i$ dinamičkih panelmodela (Arellano-Bondov procjenitelj i Blundell-Bondov procjenitelj), stoga korištenje korigiranog procjenitelja fiksnog efekta predstavlja glavni doprinos ovoga rada. Rezultati procijenjenih dinamičkih panel-modela pokazali su kako na cijene dionica na hrvatskom tržištu kapitala statistički značajan i pozitivan utjecaj imaju cijene istih dionica iz prethodnog kvartala, indeks industrijske proizvodnje, realni BDP, inflacija i kamatne stope. S druge strane, negativan utjecaj imaju indeks pouzdanja potrošača, ESI, indeks cijena nekretnina, neto štednja sektora kućanstva te dug opće države.

Ključne riječi: dinamički panel model, korigirani procjenitelj fiksnog efekta, tržište kapitala, makroekonomski pokazatelji

*J. Arnerić, dr. sc., izvanredni profesor, Ekonomski fakultetZagreb (e-mail: jarneric@efzg.hr).

** L. Vladović, student diplomskog studija Poslovne Ekonomije na Ekonomskom fakultetu Sveučilišta u Splitu, (e-mail: lvladovic00@gmail.com). Rad je primljen u uredništvo 25.09.2019. godine, a prihvaćen je za objavu 18.02.2020. godine. 


\section{UVOD}

Na cijene dionica poduzeća utječe čitavi niz faktora te veliki broj analitičara i investitora pokušava što preciznije predvidjeti kretanja na tržištima kapitala. Autori koji su istraživali utjecaj makroekonomskih pokazatelja na dioničke cijene ili, pak, prinose svoje su radove temeljili na arbitražnoj teoriji određivanja cijena (engl. Arbitrage Pricing Theory - APT) ili su istraživali informacijsku efikasnost tržišta kapitala.

Istraživanja (Benaković \& Posedel, 2010; Chen, Roll \& Ross, 1986) koja su se bazirala na APT teoriji su povezanost između makroekonomskih pokazatelja i cijena (ili prinosa) na tržištu dionica promatrala kroz prizmu faktorskih modela koji se fokusiraju na sistemski investicijski rizik, odnosno onaj dio rizika koji se ne može izbjeći diversifikacijom. Dok CAPM model (engl. Capital Asset Pricing Model) procjenjuje sistemski investicijski rizik isključivo kroz jedan faktor (tržišni portfelj), multifaktorski modeli uvode nekoliko faktora koji utječu na ostvarenje prinosa na tržištu kapitala. Chen, Roll \& Ross (1986) su kroz prizmu APT teorije pokazali kako na cijene dionica u SAD-u značajan utjecaj imaju industrijska proizvodnja, inflacija, premija rizika i krivulja prinosa. Benaković i Posedel (2010) su provele slično istraživanje i u Hrvatskoj, na uzorku 14 dionica listanih na Zagrebačkoj burzi za period od siječnja 2004. do listopada 2009. godine. Koristeći višestruku regresiju pokazale su kako je premija rizika uz CROBEX (promatran kao nezavisna varijabla) statistički značajna i pozitivna za svaku dionicu u uzorku, 3-mjesečni ZIBOR je bio pozitivan i statistički značajan za sedam dionica u uzorku, inflacija je bila negativna i statistički značajna za šest dionica u uzorku dok su se cijene nafte pokazale kao statistički značajne i pozitivne za pet dionica u uzorku. Problemi koji se javljaju prilikom istraživanja makroekonomskih determinanti cijena dionica u sklopu APT teorije je što teorija jednoznačno ne propisuje koju varijablu/e koristiti jer se dionička tržišta razlikuju po svojim karakteristikama u različitim dijelovima svijeta. Također, gospodarstva u kojima egzistiraju poduzeća se razlikuju po svojim obilježjima što otežava definiranje jedinstvenog skupa varijabli za procjenu utjecaja makroekonomskih pokazatelja na tržište kapitala.

Drugi autori istražuju povezanost između navedenih varijabli u kontekstu tržišne efikasnosti (Barbić \& Čondić-Jurkić, 2011; Mbanga \& Darrat, 2016). Stupanj efikasnosti tržišta kapitala ovisi o brzini i točnosti kojom su informacije ugrađene u cijene dionica. U slučaju nepostojanja informacijske efikasnosti tržišni sudionici bi mogli izgraditi profitabilna pravila za trgovanje i ostvariti iznadprosječne prinose uz minimalni rizik. Informacijska efikasnost ima važan utjecaj i na makrorazini jer u slučaju informacijski neefikasnih tržišta u pitanje se dovodi sposobnost tržišta u njegovoj temeljnoj ulozi alociranja fondove k najproduktivnijim sektorima ekonomije. Mbanga i Darrat (2016) zaključuju kako ne postoji statistički značaj- 
na veza između promjena u monetarnim varijablama (mjereno kroz monetarnu bazu) i cijena dionica, odnosno kako je američko tržište promatrano kroz vrijednost S\&P500 indeksa efikasno u odnosu na dostupne informacije o monetarnoj politici. S druge pak strane, američka tržišta kapitala su se pokazala neefikasnima u odnosu na dostupne informacije o potezima fiskalne politike (aproksimirane kroz realne, ciklički prilagođene budžetske deficite) jer su se varijable fiskalne politike pokazale statistički značajnima u objašnjenju kretanja S\&P500 indeksa. Barbić i Čondić-Jurkić (2011) polaze od pretpostavke pri kojoj je tržište kapitala efikasno ukoliko postoji kointegrirajuća veza između makroekonomskih varijabli i tržišnog indeksa. Drugim riječima, ako postoji dugoročna veza između makroekonomskih varijabli i dioničkog indeksa, makroekonomske varijable su značajne i konzistentno ukalkulirane u prinose na dioničkim tržištima. Istraživanje provedeno na uzorku zemalja srednje i istočne Europe (Hrvatske, Slovenije, Češke, Poljske i Mađarske) pokazalo je kako kointegracija između makroekonomskih varijabli i kretanja dioničkog indeksa postoji za većinu varijabli. Na primjeru Hrvatske kointegracija postoji između sljedećih parova varijabli: CROBEX-a i devizne rezerve, CROBEX-a i harmoniziranog indeksa potrošačkih cijena, CROBEX-a i M4, no ne postoji kointegracija između CROBEX-a i kamatnih stopa na tržištu novca. Nadalje, rezultati dodatne analize pokazuju kako na vrijednost tržišnog indeksa u Sloveniji utječu inflacija i kamatne stope na tržištu novca dok u Češkoj na vrijednost tržišnog indeksa utječu devizne rezerve i ponuda novca mjerena kroz monetarni agregat M3. To podrazumijeva da se slovensko i češko tržište kapitala u ovakvom kontekstu ne mogu smatrati efikasnima jer investitori koristeći makroekonomske pokazatelje u kratkom roku mogu ostvariti iznadprosječne prinose. Međutim, ostaje veliko pitanje u kojoj se mjeri ovakvi rezultati mogu iskoristiti s obzirom na postojanje transakcijskih troškova, kašnjenje u informiranju i općenito neizvjesnost koja je povezana s tržištima kapitala u razvoju.

Cilj je ovoga rada istražiti povezanost između makroekonomskih pokazatelja hrvatskog gospodarstva i cijena dionica na Zagrebačkoj burzi. U tu svrhu koristit ce se panel-podatci i korigirani procjenitelj fiksnog efekta LSDVc (engl. Least Squares Dummy Variable Corrected). Veliki broj istraživanja na ovu temu koristio je panel-analizu, no pritom su najčešće korišteni različiti procjenitelji statičkih panel-modela (procjenitelj združenog modela i procjenitelj s fiksnim efektom) i dinamičkih panel-modela (Arellano-Bondov procjenitelj i Blundell-Bondov procjenitelj). Rezultati dobiveni korištenjem korigiranog procjenitelja fiksnog efekta moći će se usporediti s već postojećim istraživanjima čime će se doprinijeti potvrđivanju ili opovrgavanju dosadašnjih rezultata.

U sljedećem poglavlju dan je pregled literature, nakon čega slijedi kratak prikaz trendova na hrvatskom tržištu kapitala. U četvrtom poglavlju specificiran je korišteni panel-model i panel-podatci te su prikazani i interpretirani rezultati procijenjenih modela dok se posljednji dio rada odnosi na zaključak. 


\section{PREGLED LITERATURE}

Provedena empirijska istraživanja o povezanosti između makroekonomskih varijabli i tržišta kapitala mogu se podijeliti na dva dijela. Jedan dio istraživanja kao zavisnu varijablu promatra dioničke prinose na dionice (najčešće preko prinosa na vrijednost burzovnog indeksa). Drugi dio istraživanja sagledava utjecaj makroekonomskih varijabli na razvoj tržišta kapitala koji je aproksimiran varijablom omjera tržišne kapitalizacije domaćih dionica i BDP-a.

\subsection{Istraživanja na razini burzovnih indeksa}

Maysami, Howe i Hamzah (2004) ispituju vezu između makroekonomskih varijabli i burzovnih indeksa u Singapuru koristeći VEC model. Promatran je utjecaj na burzovne indekse koji prate financijska poduzeća, burzovne indekse koji prate hotelska poduzeća i burzovne indekse koji prate nekretninska poduzeća. Rezultati pokazuju kako na burzovni indeks koji prati financijska poduzeća pozitivno utječu inflacija i kratkoročne kamatne stope, a negativno utječu dugoročne kamatne stope i deprecijacija domaće valute. Na burzovni indeks koji prati hotelska poduzeća pozitivno utječu deprecijacija domaće valute i industrijska proizvodnja, a negativno utječe inflacija. Na posljednji promatrani indeks, koji prati nekretninska poduzeća, pozitivno utječu inflacija, industrijska proizvodnja, kratkoročne kamatne stope i monetarni agregat M2 dok negativno utječe deprecijacija domaće valute i dugoročne kamatne stope.

Ratanapakorn i Sharma (2007) istražuju vezu između prinosa na američkom tržištu kapitala i makroekonomskih varijabli korištenjem VEC modela i Grangerovog testa uzročnosti te zaključuju kako makroekonomski pokazatelji za američko gospodarstvo ne utječu na prinose na tržištu kapitala u kratkom roku dok u dugom roku postoji uzročnost. Drugim riječima, makroekonomske varijable (M1, inflacija, kamatna stopa na trezorske zapise, kamatna stopa na dugoročne državne obveznice, tečaj $¥ / \$$ ) utječu na kretanje tržišnog indeksa u dugom roku dok između industrijske proizvodnje i istog tržišnog indeksa u dugom roku postoji obostrana uzročnost. Nepostojanje uzročnosti u kratkom roku autori objašnjavaju činjenicom da cijene dionica u kratkom roku slijede random-walk i makroekonomski pokazatelji u takvoj situaciji teško mogu objasniti kretanja na tržištima kapitala.

Humpe i Macmillan (2009) istražuju makroekonomske varijable koje utječu na kretanja na američkom i japanskom tržištu kapitala za razdoblje od siječnja 
1965. godine do lipnja 2005. godine. Rezultati VEC modela pokazali su kako na američko dioničko tržište pozitivno utječe industrijska proizvodnja dok je utjecaj prinosa na državne obveznice i inflacije negativno povezan s dioničkim tržištem. Rezultati za Japan pokazuju kako na cijene dionica također pozitivno djeluje rast industrijske proizvodnje dok je utjecaj ponude novca negativan (zbog keynezijanske zamke likvidnosti koja je pogodila Japan kasnih 1990-ih i početkom 2000-ih). Dodatno, utjecaj inflacije je negativan, ali isključivo se manifestira indirektno, odnosno djelovanjem preko koeficijenta industrijske proizvodnje.

Hsing (2011) je u svom radu istraživao makroekonomske varijable koje utječu na cijene dionica na primjeru hrvatskog tržišta kapitala koristeći EGARCH model. Provedena analiza na podatcima od 1997. godine do zaključno s prvim kvartalom 2010. godine pokazala je kako realni BDP, odnos M1 i BDP-a, vrijednost njemačkog dioničkog indeksa i prinosi na državne obveznice u europodručju pozitivno utječu na CROBEX dok odnos proračunskog deficita i BDP-a, realne domaće kamatne stope, tečaj HRK/USD i očekivana stopa inflacije negativno utječu na vrijednost hrvatskog tržišnog indeksa.

Subeniotis, Papadopoulos, Tampakoudis i Tampakoudi (2011) koriste panelmodel s fiksnim efektom kako bi istražili utjecaj makroekonomskih varijabli na burzovne indekse 12 zemalja članica Europske unije. Rezultati istraživanja pokazali su kako tržišna kapitalizacija i ESI (engl. Economic Sentiment Indicator) imaju pozitivan i statistički značajan utjecaj na vrijednost burzovnih indeksa. Utjecaj industrijske proizvodnje je značajan i negativan dok se inflacija nije pokazala statistički značajnom.

Arouri i Rault (2012) ispituju vezu između cijena nafte i tržišta kapitala u Bahreinu, Kuvajtu, Omanu i Saudijskoj Arabiji pri čemu istražuju kointegraciju u sklopu panel-modela te utjecaj cijena nafte na tržišta kapitala koristeći model naizgled nepovezanih regresija (engl. seemingly unrelated regressions). Rezultati Westerlundovog testa pokazali su kako između cijene nafte i cijena dionica postoji kointegracija. Nadalje, model naizgled nepovezanih regresija pokazao je kako cijene nafte pozitivno utječu na cijene dionica u Bahreinu, Kuvajtu i Omanu dok je utjecaj cijena nafte na cijene dionica u Saudijskoj Arabiji negativan.

Pradhan, Arvin, Hall i Bahmani (2014) na uzorku zemalja članica ASEAN regionalnog foruma promatraju odnos između razvoja bankovnog sektora, razvoja tržišta kapitala i makroekonomskih varijabli (direktne strane investicije, inflacija, otvorenost trgovine i državna potrošnja). Rezultati Pedronijevog panel-kointegracijskog testa pokazali su da postoji kointegracija između razvoja tržišta kapitala, razvoja bankovnog sektora, ekonomskog rasta i izabranih makroekonomskih varijabli. Daljnja analiza pokazala je kako u kratkom roku na razvoj tržišta kapitala utjecaj ima isključivo razvoj bankovnog sektora dok razvoj tržišta kapitala utječe na ekonomski rast, otvorenost trgovine, inflaciju i državnu potrošnju. 
Radman Peša i Festić (2014) u svom radu istražuju vezu između burzovnih indeksa (u BiH, Bugarskoj, Hrvatskoj, Crnoj Gori, Srbiji, Sloveniji i Rumunjskoj) i glavnih makroekonomskih indikatora pri čemu se koriste panel-regresijom te TSLS (engl. Two Stage Least Squares) metodom za model s fiksnim efektom. Rezultati procijenjenog panel-modela pokazuju kako kapitalni priljevi, BDP, industrijska proizvodnja i neto izvoz imaju pozitivan i statistički značajan utjecaj na burzovne indekse. S druge strane, državni dug i kratkoročne kamatne stope imaju negativan i statistički značajan utjecaj.

Mensi, Hammoudeh, Yoon i Balcilar (2016) su proučavali utjecaj makroekonomskih faktora i državnog rizika na dioničke prinose u Bahreinu, Kuvajtu, Omanu, Kataru, Saudijskoj Arabiji i Ujedinjenim Arapskim Emiratima. Rezultati simetričnog jednorežimskog dinamičkog panel-modela pokazuju kako statistički značajan utjecaj na dioničke prinose imaju isti prinosi iz prethodnog razdoblja (s jednim vremenskim pomakom), prinosi na globalni burzovni indeks, prinosi na islamski burzovni indeks, cijene nafte tipa BRENT (pozitivan utjecaj), kratkoročne i dugoročne kamatne stope u SAD-u te promjena cijene zlata (negativan utjecaj). Nadalje, procijenjeni modeli pokazali su kako se samo financijski rizik (odnosi se na sposobnost države da financira svoje obveze) pokazao statistički značajnim, odnosno smanjenje financijskog rizika stimulira dioničke prinose u promatranim zemljama.

Assefa, Esqueda i Mollick (2017) koriste panel-model s fiksnim efektom i Blundell-Bondov procjenitelj kako bi istražili vezu između makroekonomskih varijabli i dioničkih prinosa. Svoje istraživanje proveli su na burzovnim indeksima 21 razvijene zemlje i 19 zemalja u razvoju u periodu od 1999. godine do 2013. godine. Rezultati panel-modela s fiksnim efektom pokazali su kako prinosi na globalni burzovni indeks (pozitivno) i kamatne stope (negativno) značajno utječu na dioničke prinose u razvijenim zemljama i zemljama u razvoju. Kod razvijenih zemalja dodatno su se značajnim pokazali rast realnog BDP-a (pozitivan utjecaj) i promjena realnog efektivnog tečaja (negativan utjecaj). Za zemlje u razvoju još se značajnom i pozitivnom pokazala varijabla koja aproksimira volatilnost na tržištu. Rezultati dobiveni korištenjem Blundell-Bondovog procjenitelja sugeriraju kako u objema grupama zemalja na dioničke prinose pozitivno utječu prinosi na globalni burzovni indeks dok su se kamatne stope pokazale značajnima i negativnima samo za razvijene zemlje.

Barbić i Čondić Jurkić (2017) istražuju razlikuje li se utjecaj makroekonomskih varijabli na prinose na tržištu kapitala među „novim“ i „starim“ EU članicama. Rezultati su pokazali kako su za razvijene članice EU varijable koje statistički značajno utječu na prinose na tržištima kapitala inflacija (pozitivan utjecaj) i kamatna stopa na tržištu novca (negativan utjecaj). Panel-model za EU tržišta u razvoju pokazao je kako je statistički značajna i pozitivna varijabla koja se odnosi na državni dug. 
Jamaludin, Ismail i Manaf (2017) istražuju utjecaj makroekonomskih varijabli na konvencionalne burzovne indekse i islamske burzovne indekse u Singapuru, Maleziji i Indoneziji koristeći združeni panel-model. Rezultati panel-modela pokazuju kako statistički značajan utjecaj na konvencionalne i islamske burzovne indekse imaju inflacija (negativan utjecaj) i realni efektivni devizni tečaj (pozitivan utjecaj).

\subsection{Istraživanja na razini razvoja tržišta kapitala}

Billmeier i Massa (2009) proučavaju što pokreće razvoj tržišta kapitala u zemljama Bliskog istoka i središnje Azije. Autori su se prilikom ekonometrijske analize koristili panel-modelom s fiksnim efektom. Promatrajući uzorak svih zemalja na razvoj tržišta kapitala pozitivnima su se pokazale doznake, institucije te varijable dohotka, investicija i likvidnosti na tržištima kapitala s vremenskim pomakom. Dodatno, autori su ukupan uzorak zemalja podijelili na zemlje koje su bogate ugljikovodicima i one koje nisu bogate ugljikovodicima. Kod zemalja koje nisu bogate naftom, pozitivnima i statistički značajnima pokazale su se doznake, institucije i varijabla likvidnosti na tržištima kapitala s vremenskim pomakom. U uzorku zemalja bogatih naftom doznake i institucije pokazale su se statističkim neznačajnima dok su se značajnima isključivo pokazale varijable investicija i dohotka s vremenskim pomakom.

Yartey (2010) u svom istraživanju proučava institucionalne i makroekonomske determinante razvoja tržišta kapitala u 42 gospodarstva u razvoju za period od 1990. godine do 2004. godine. Koristeći Arellano-Bondov procjenitelj dinamičkog panela zaključuje kako pozitivan utjecaj na razvoj tržišta kapitala ima vrijednost zavisne varijable s vremenskim pomakom, razvoj bankovnog sektora, likvidnost na tržištu, bruto domaće investicije i BDP per capita. Također, u jednom od modela statistički značajnim i pozitivnim su se pokazali kapitalni priljevi. Uključivanjem institucionalnih varijabli u panel pokazalo se kako na razvoj tržišta kapitala značajno utječu institucionalni faktori poput zakona i poretka, demokratske odgovornosti i kvalitete birokracije.

Şükrüoğlu i Nalin (2014) na uzorku od 19 europskih zemalja, koristeći Arellano-Bondov procjenitelj dinamičkog panela zaključuju kako vrijednost zavisne varijable s vremenskim pomakom, likvidnost na tržištu te bruto domaća štednja pozitivno utječu na razvoj tržišta kapitala dok inflacija i odnos monetarnog agregata M3 i BDP-a negativno utječu na razvoj tržišta kapitala.

Olgić Draženović i Kusanović (2016) koristeći panel-model s fiksnim efektom istražuju determinante razvoja tržišta kapitala u Hrvatskoj, Češkoj, Mađarskoj, 
Poljskoj, Sloveniji i Slovačkoj. Rezultati procijenjenih panel-modela za korištene makroekonomske pokazatelje pokazuju kako štednja i rast BDP-a imaju pozitivan utjecaj dok inflacija ima negativan utjecaj na razvoj promatranih tržišta kapitala.

\section{TRENDOVI HRVATSKOG TRŽIŠTA DIONICA}

Na Slici 1 prikazano je kretanje glavnog dioničkog indeksa Zagrebačke burze od 2007. godine. CROBEX je najvišu vrijednost u promatranom razdoblju zabilježio u siječnju 2008. godine kada se kretao pri razini od oko 5280 bodova. Ubrzo nakon toga, kao posljedica recesije, vrijednost CROBEX-a spustila se na nisku razinu od 1262 boda u ožujku 2009. godine. Vrijednost CROBEX-a uspjela se djelomično oporaviti do 2011. godine kada je dosegla razinu od 2200 bodova, nakon čega slijedi period pada i stagnacije koji je trajao do 2016. godine. Posljednji značajniji rast glavnog dioničkog indeksa Zagrebačke burze započeo je pri početku 2016. godine i trajao je do ožujka 2017. godine. Upravo tada su eskalirali problemi u Agrokor grupi koji su se negativno odrazili i na čitavo hrvatsko tržište kapitala.

Slika 1:

KRETANJE CROBEX-A

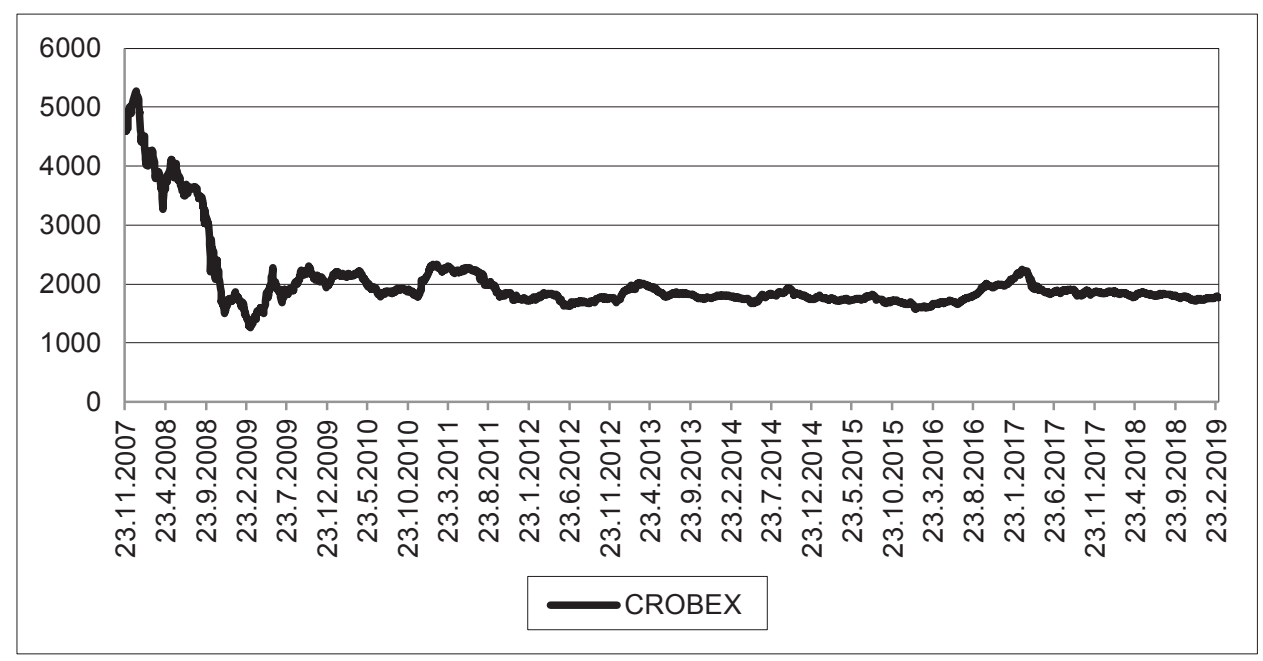

Izvor: Zagrebačka burza

Iz Slike 2 može se vidjeti kako je pokazatelj tržišne kapitalizacije svoju najvišu vrijednost u promatranom razdoblju dosegao u 2007. godini kada se kretao 
na razini od 394 milijarde kuna. Pojava svjetske financijske krize odrazila se i na kretanje tržišne kapitalizacije na hrvatskom tržištu kapitala. U 2008. godini tržišna kapitalizacija vrijednosnih papira na Zagrebačkoj burzi smanjila se za 55\% u odnosu na 2007. godinu. Prema kraju promatranog razdoblja tržišna kapitalizacija se tek ponešto oporavila te se u 2018. godini kretala pri razini od 234 milijarde kuna. Dodatno, može se vidjeti kako na hrvatskom tržištu kapitala prevladavaju dionice i obveznice. Udio komercijalnih zapisa, prava i strukturiranih proizvoda u ukupnoj tržišnoj kapitalizaciji je zanemariv. Kroz promatrano razdoblje udio dionica u ukupnoj tržišnoj kapitalizaciji opada, no i dalje je tržišna kapitalizacija dionica viša od tržišne kapitalizacije obveznica.

Slika 2:

\section{KRETANJE TRŽIŠNE KAPITALIZACIJE NA ZAGREBAČKOJ BURZI}

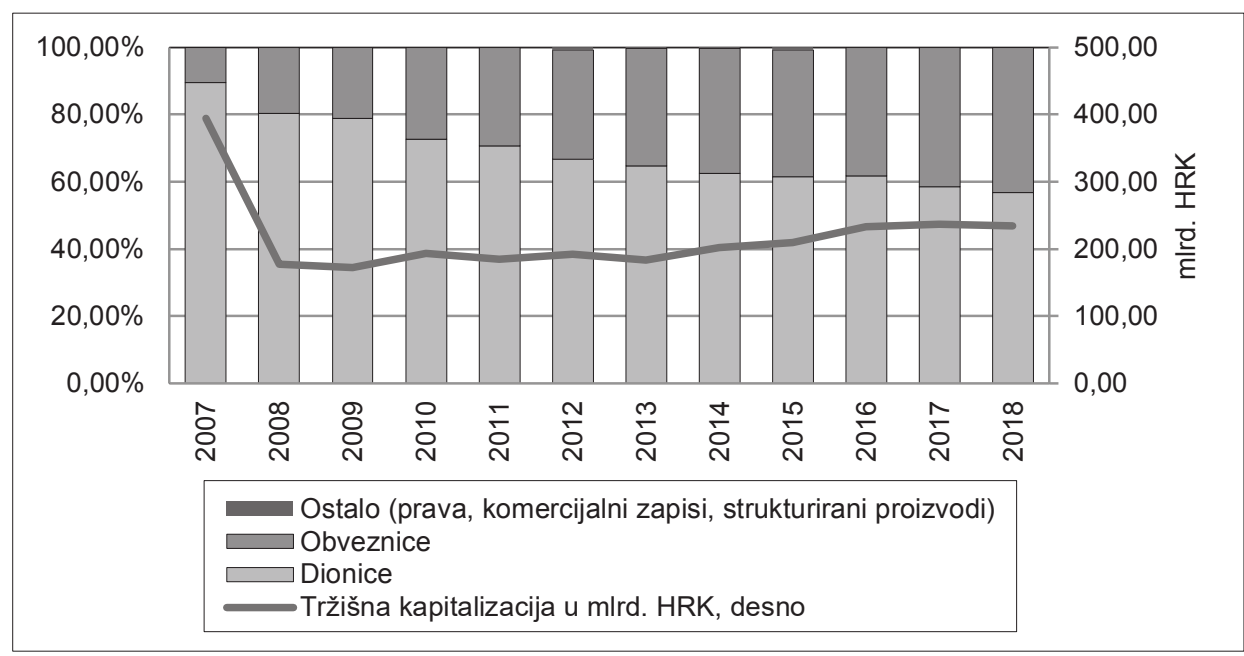

Izvor: Zagrebačka burza

Ukupni promet prikazan na Slici 3 dobio se zbrajanjem ukupnog prometa unutar knjige ponuda te bloka prometa dionicama i obveznicama i OTC prometa. Pokazatelji prometa također pokazuju u kolikom su razmjeru posljednja financijska kriza i recesija negativno utjecale na hrvatsko tržište kapitala, odnosno koliko je hrvatsko tržište kapitala u pretkriznom razdoblju bilo napuhano. Ukupan promet je s razine od 66,5 milijardi kuna u 2007. godini pao na razinu od 10,91 milijardu kuna u 2009. godini. U periodu od 2009. do 2016. godine, ukupni ostvareni prometi djelomično su se oporavili i dosegli razinu od oko 30 milijardi kuna da bi potom ponovno nastavili padati te se u 2018. godini kretali pri razini od 15,79 milijardi kuna. Promet unutar knjige ponuda te bloka prometa dionicama i 
obveznicama smanjio se s razine od 27 milijardi kuna u 2007. godini na razinu od 3,85 milijardi kuna u 2012. godini. U razdoblju od 2012. do 2017 godine promet se unutar knjige ponuda te bloka prometa dionicama i obveznicama stabilizirao na razini od oko 3,7 milijardi kuna, no u 2018. godini ponovno je zabilježio pad od $22 \%$ u odnosu na 2017. godinu te je iznosio 2,86 milijardi kuna.

Slika 3:

\section{PROMETI NA ZAGREBAČKOJ BURZI}

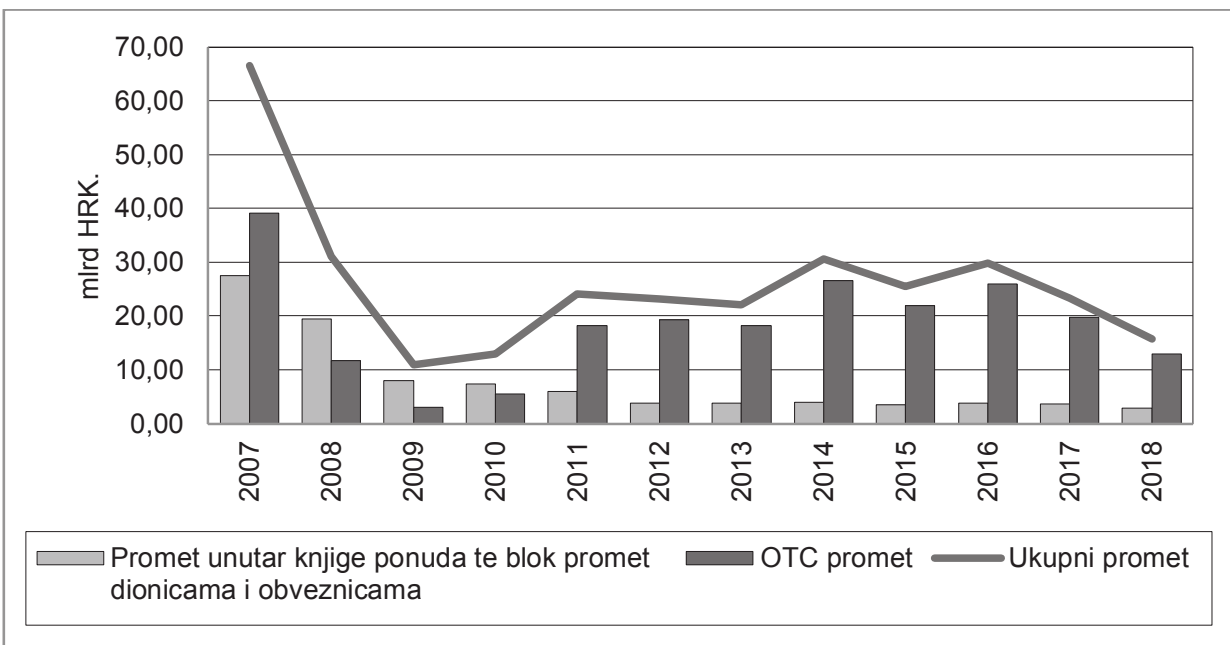

Izvor: Zagrebačka burza

Na Slici 4 prikazana su kretanja na tržištima kapitala CEE zemalja. Godišnje stope promjene izračunate su kao rast/pad vrijednosti indeksa na posljednji dan trgovanja u tekućoj godini u odnosu na vrijednost indeksa na posljednji dan trgovanja u prethodnoj godini. Godišnja promjena CROBEX-a u posljednjem je stupcu svake godine i prikazana je bijelim stupcem s točkicama. U pretkriznom razdoblju (2006. i 2007. godina) dionice na hrvatskom tržištu kapitala zabilježile su brži rast od usporedivih dionica u CEE zemljama. Dolaskom krize sva CEE tržišta zabilježila su dvoznamenkasti pad koji je za većinu zemalja bio veći od 50\%. Od 2009. do 2018 godine najviše razdoblja (osam) sa zabilježenim godišnjim rastom imao je litvanski burzovni indeks Vilnius SE General. Estonski, latvijski, poljski, mađarski i rumunjski dionički indeksi zabilježili su sedam godina rasta i tri godine pada vrijednosti. Burze u Slovačkoj, Bugarskoj i Sloveniji rasle su šest godina, a padale četiri godine. Burzovni indeksi za Hrvatsku i Češku zabilježili su pet godina rasta te pet godina pada. Zanimljivo je da su u 2017. godini svi burzovni indeksi u CEE zemljama osim CROBEX-a zabilježili rast. U 2017. godini materijalizirali su se 
svi problemi u Agrokor grupi što se u velikoj mjeri odrazilo i na čitavo hrvatsko tržište kapitala. U posljednjoj promatranoj godini jedino je slovački burzovni indeks SAX zabilježio rast od 2,07\% dok su ostali promatrani indeksi bilježili pad vrijednosti u odnosu na 2017. godinu.

\section{Slika 4:}

\section{GODIŠNJA PROMJENA VRIJEDNOSTI BURZOVNIH INDEKSA U CEE ZEMLJAMA}
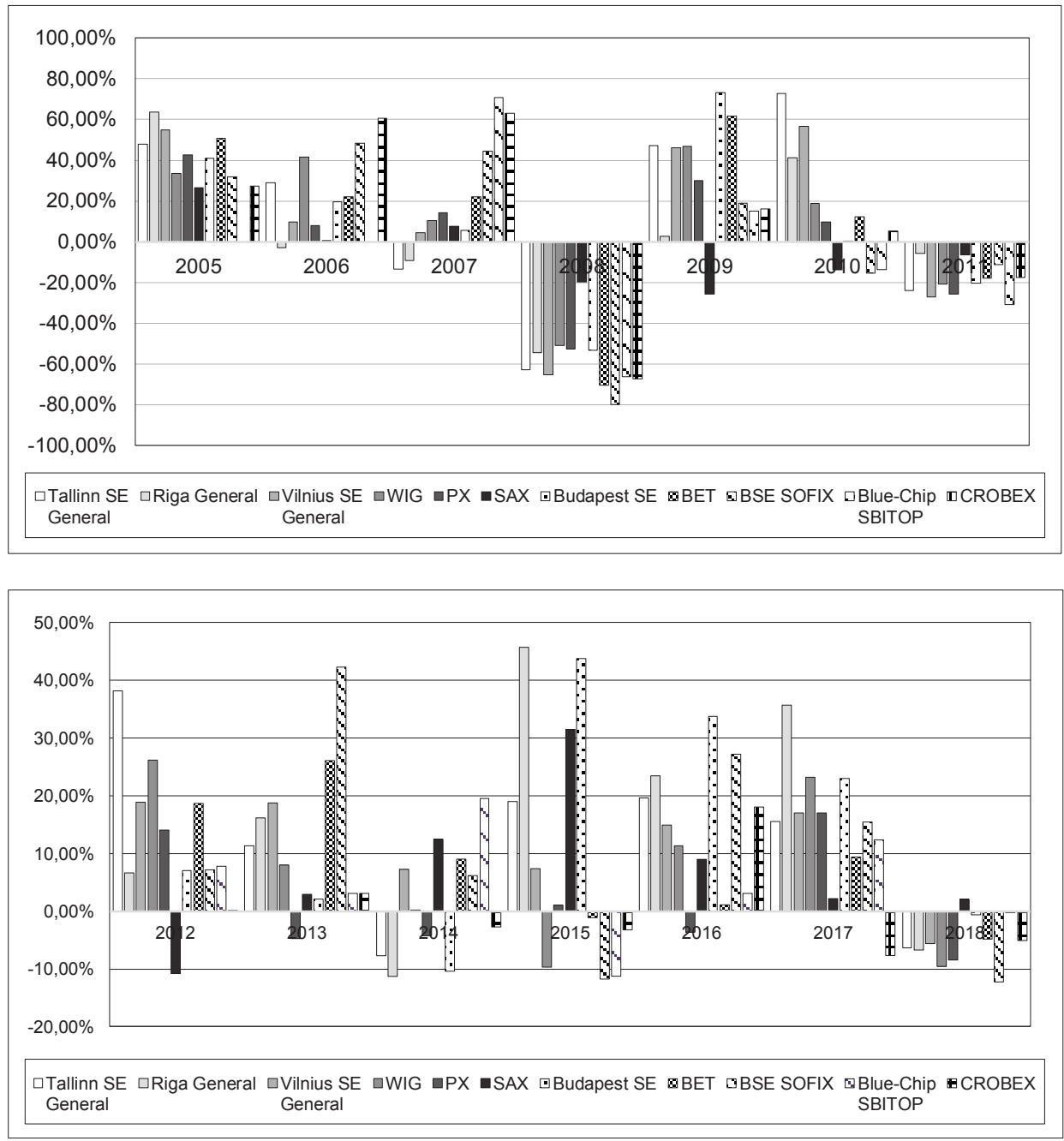

Izvor: prikaz autora prema podacima https://www.investing.com/indices/world-indices 


\section{METODOLOGIJA I PODATCI}

Za istraživanje veze između cijena dionica i makroekonomskih pokazatelja hrvatskog gospodarstva formiran je dinamički panel-model i korišten korigirani procjenitelj fiksnog efekta. Korištenjem panel-podataka omogućava se istovremeno analiziranje vremenske i prostorne komponente neke pojave. Panel-podatci omogućavaju definiranje i testiranje kompliciranijih ekonometrijskih modela, sadrže veći broj podataka nego pripadajući prostorni podatci ili pripadajući vremenski nizovi, manje su osjetljivi na netipične vrijednosti (engl. outliers), omogućuju mjerenje različitosti unutar jedinica promatranja. Nadalje, procjene dobivene panelanalizom su preciznije jer se zavisna varijabla mijenja po jedinicama promatranja i po vremenu, pristranost parametara koja se pojavljuje zbog nedostataka podataka se umanjuje korištenjem panel-podataka, umanjuje se problem multikolinearnosti. Procijenjeni dinamički panel-model može se zapisati na sljedeći način:

$$
y_{i t}=\mu+\gamma y_{i, t-1}+x_{i t}^{\prime} \beta+\alpha_{i}+\varepsilon_{i t} ; i=1, \ldots, N, t=1, \ldots, T
$$

pri čemu je:

- $\mathrm{N}$ broj jedinica promatranja,

- T broj razdoblja,

- $\mu$ konstantni član,

- $\gamma$ autoregresijski koeficijent,

- $X_{i t}$ je vrijednost parametara dimenzije K (matrica dimenzije Kx1), vektor koji sadržava vrijednosti K-nezavisnih varijabli i-te jedinice promatranja u razdoblju t,

- $\beta$ je vektor parametara dimenzije K (matrica dimenzije Kx1) koji sadrži parametre koje treba procijeniti $\beta=\left[\beta_{1}, \beta_{2}, \ldots, \beta_{\mathrm{K}}\right]^{\prime}$

- $\alpha_{i}$ je fiksni ili slučajni efekt za svaku jedinicu promatranja (ili specifična pogreška i-te jedinice promatranja)

- $\varepsilon_{i t}$ je greška relacije i-te jedinice promatranja u razdoblju t i pretpostavlja se da su $\varepsilon_{i t}$ nezavisno i identično distribuirane slučajne varijable po jedinicama promatranja i vremenu, sa sredinom 0 i varijancom $\sigma_{\varepsilon}^{2}$,

Također se pretpostavlja da su svi $X_{i t k}$ nezavisni s $\varepsilon_{i t}$ za sve i, t, k.

Prilikom izbora procjenitelja dinamičkog panel-modela potrebno je sagledati broj jedinica i razdoblja promatranja. Arellano-Bondov (1991) i BlundellBondov (1998) su adekvatni procjenitelji kada je broj jedinica promatranja velik, 
a vremensko razdoblje relativno maleno. $\mathrm{S}$ druge strane, korigirani procjenitelj fiksnog efekta adekvatan je za korištenje kada je broj jedinica promatranja malen ili srednje dimenzije i kada je broj razdoblja veći od trideset (Škrabić Perić, 2019). Nadalje, Bruno (2005) je pokazao da korigirani procjenitelj fiksnog efekta ima bolja svojstva u većini simuliranih slučajeva od AB i BB procjenitelja u slučaju kada je broj jedinica promatranja malen. Veza između cijena dionica i makroekonomskih pokazatelja hrvatskog gospodarstva u ovom radu istražena je za devet dionica (broj jedinica promatranja) sastavnica dioničkog indeksa CROBEX10 i četrdeset kvartala (broj vremenskih razdoblja). Dakle, korištenje korigiranog procjenitelja fiksnog efekta je opravdano budući je $T>N$. Nadalje, u predloženom su modelu nezavisne varijable promjenjive $\mathrm{u}$ vremenu, ali su, pak, jednake za sve jedinice promatranja što ublažava mogući problem endogenosti. Problem endogenosti se dodatno eliminira uključivanjem zavisne varijable ujedno i kao nezavisne varijable iz prethodnog razdoblja, što je ovdje i učinjeno. Osim toga, uključivanjem cijene s jednim vremenskim pomakom apsorbira se autoregresijska dinamika te se istovremeno uklanja potreba za diferenciranjem varijabli. Dodatno, korigirani procjenitelj fiksnog efekta je nepristran i asimptotski konzistentan ako je $\mathrm{N}$ relativno malen te ako je ispunjen uvjet egzogenosti.

Istraživanjem je obuhvaćen vremenski period od prvog kvartala 2009. godine do posljednjeg kvartala 2018. godine. Tromjesečne cijene zatvaranja dionica sastavnica dioničkog indeksa CROBEX10 (AD Plastik d.d., Adris grupa d.d., Arena Hospitality Group d.d., Atlantic grupa d.d., Atlantska plovidba d.d., Ericsson Nikola Tesla d.d., HT d.d., Končar d.d. i Podravka d.d.) korištene su kao zavisna varijabla. Jedina dionica sastavnica CROBEX10 indeksa koja je izostavljena je dionica Valamar Riviere d.d. Navedena dionica je ispuštena jer je u jednom dijelu perioda obuhvaćenog istraživanjem došlo do ukidanja uvrštenja dionice na Zagrebačku burzu. U Tablici 1 navedene su sve korištene varijable zajedno s pripadajućim objašnjenjem te izvorom podatka. Cijene dionica i sve nezavisne varijable (osim 3-mjesečnog ZIBOR-a) su desezonirane i izražene u obliku prirodnog logaritma. Vrijednost 3-mjesečnog ZIBOR-a je desezonirana, ali nije izražena u obliku prirodnog logaritma. Vremenske serije koje se odnose na indeks industrijske proizvodnje, realni BDP, indeks potrošačkih cijena, ESI i indeks pouzdanja potrošača su preuzete kao već desezonirane vremenske serije. Vremenske serije za preostale korištene varijable su desezonirane koristeći EViews statistički paket. 
Tablica 1:

\section{POPIS KORIŠTENIH VARIJABLI}

\begin{tabular}{|c|c|c|}
\hline Oznaka varijable & Definicija & Izvor \\
\hline Cijena & $\begin{array}{l}\text { Tromjesečne cijene zatvaranja dionica sastavnica dioničkog } \\
\text { indeksa CROBEX10 (s izuzećem dionice Valamar Riviere d.d.) }\end{array}$ & $Z S E$ \\
\hline IIP & $\begin{array}{l}\text { Prosječna kvartalna vrijednost indeksa industrijske } \\
\text { proizvodnje (originalni indeks, 2015=100) }\end{array}$ & $H N B$ \\
\hline RBDP & Realni bruto domaći proizvod u mlrd. HRK & $H N B$ \\
\hline IPC & Indeks potrošačkih cijena (originalni indeks, $2015=100$ ) & $H N B$ \\
\hline ZIBOR3mj & 3-mjesečni ZIBOR & $H N B$ \\
\hline ESI & $\begin{array}{l}\text { ESI (engl. Economic Sentiment Indicator) je kompozitni } \\
\text { indikator koji se sastoji od pet sektorskih indikatora } \\
\text { pouzdanja s različitim ponderima, a to su poslovni optimizam } \\
\text { u industriji (40\%), poslovni optimizam u uslugama (30 \%), } \\
\text { indeks pouzdanja potrošača (20 \%), poslovni optimizam u } \\
\text { građevinarstvu (5\%) te poslovni optimizam u trgovini }(5 \%) \text {. }\end{array}$ & $\begin{array}{c}\text { Europska } \\
\text { komisija }\end{array}$ \\
\hline IPP & $\begin{array}{l}\text { Indeks pouzdanja potrošača. Indeks pouzdanja potrošača } \\
\text { se računa na temelju anketnog istraživanja potrošača te } \\
\text { uključuje očekivanja potrošača o ekonomskoj i financijskoj } \\
\text { situaciji u sljedećih } 12 \text { mjeseci. }\end{array}$ & $H N B$ \\
\hline NEKRETNINE & Indeks cijena stambenih nekretnina (bazni indeksi, 2015=100) & $H N B$ \\
\hline DOD & $\begin{array}{l}\text { Ukupni dug opće države (u mil. HRK), koji je jednak zbroju } \\
\text { inozemnog duga opće države i unutarnjeg duga opće države. } \\
\text { Jedan i drugi se dobiju kao zbroj duga središnje države, duga } \\
\text { fondova socijalne sigurnosti i duga lokalne države i kada se } \\
\text { od njih oduzmu konsolidacijski elementi. }\end{array}$ & $H N B$ \\
\hline NETO ŠTEDNJA & $\begin{array}{l}\text { Višak štednje (zbroj kunskih i deviznih depozita (štednih } i \\
\text { oročenih)) nad kreditima sektora kućanstva u mil. HRK }\end{array}$ & $H N B$ \\
\hline
\end{tabular}

Izvor: prikaz autora

\section{REZULTATI DINAMIČKOG PANEL-MODELA}

Kao inicijalni procjenitelj za sve modele korišten je Arellano-Bondov procjenitelj. Matrica varijanci i kovarijanci za svaki se procijenjeni model dobila na temelju 100 ponavljanja bootstraping metodom. Ukupno je procijenjeno 16 modela koji su podijeljeni u tri tablice: Tablica 2, Tablica 3 i Tablica 4. Razlike među modelima unutar pojedine tablice ogledaju se u dvjema stvarima. Kroz modele unutar pojedine tablice mijenjane su varijable koje se mogu supstituirati, a to su parovi varijabli indeksa industrijske proizvodnje i realnog BDP-a te varijabli ESI- 
ja i indeksa pouzdanja potrošača. Druga razlika odnosi se na uključivanje varijable koja se odnosi na indeks cijena nekretnina koja je uključena u drugom dijelu tablice s rezultatima.

\section{Tablica 2:}

\section{REZULTATI MODELA 1-8}

\begin{tabular}{|c|c|c|c|c|c|c|c|c|}
\hline & $\begin{array}{c}\text { Model } \\
1\end{array}$ & $\begin{array}{c}\text { Model } \\
2\end{array}$ & $\begin{array}{c}\text { Model } \\
3\end{array}$ & $\begin{array}{c}\text { Model } \\
4\end{array}$ & $\begin{array}{c}\text { Model } \\
5\end{array}$ & $\begin{array}{c}\text { Model } \\
6\end{array}$ & $\begin{array}{c}\text { Model } \\
7\end{array}$ & $\begin{array}{c}\text { Model } \\
8\end{array}$ \\
\hline \multirow[t]{2}{*}{ L.Cijena } & $0.968^{* * * *}$ & $0.968^{* * *}$ & $0.968^{* * * *}$ & $0.967^{* * *}$ & $0.973^{* * *}$ & $0.973^{* * * *}$ & $0.972^{* * *}$ & $0.969^{* * *}$ \\
\hline & $(0.0264)$ & $(0.0266)$ & $(0.0267)$ & $(0.0269)$ & $(0.0267)$ & $(0.0266)$ & $(0.0263)$ & $(0.0262)$ \\
\hline \multirow[t]{2}{*}{ IIP } & $0.499^{*}$ & $0.702^{* *}$ & & & $0.833^{* * *}$ & $1.093^{* * * *}$ & & \\
\hline & $(0.277)$ & $(0.283)$ & & & $(0.310)$ & $(0.348)$ & & \\
\hline \multirow[t]{2}{*}{ RBDP } & & & 0.422 & $0.625^{* *}$ & & & $1.760^{* * *}$ & $2.013^{* * *}$ \\
\hline & & & $(0.286)$ & $(0.278)$ & & & $(0.458)$ & $(0.473)$ \\
\hline \multirow[t]{2}{*}{ IPC } & 0.823 & $1.144^{* *}$ & 0.443 & 0.616 & $1.022^{* *}$ & $1.372^{* * *}$ & $0.765^{* *}$ & $0.920^{* *}$ \\
\hline & $(0.505)$ & $(0.520)$ & $(0.386)$ & $(0.391)$ & $(0.463)$ & $(0.504)$ & $(0.378)$ & $(0.390)$ \\
\hline \multirow[t]{2}{*}{ ZIBOR3mj } & $0.0116^{* *}$ & $0.0148^{* * * *}$ & $0.0111^{*}$ & $0.0134^{* * * *}$ & $0.0164^{* *}$ & $0.0238^{* * * *}$ & $0.0154^{* * *}$ & $0.0294^{* * *}$ \\
\hline & $(0.00578)$ & $(0.00525)$ & $(0.00606)$ & $(0.00518)$ & $(0.00677)$ & $(0.00672)$ & $(0.00672)$ & $(0.00722)$ \\
\hline \multirow[t]{2}{*}{ ESI } & -0.170 & & -0.144 & & $-0.341^{* *}$ & & $-0.742^{* * *}$ & \\
\hline & $(0.146)$ & & $(0.148)$ & & $(0.168)$ & & $(0.213)$ & \\
\hline \multirow[t]{2}{*}{ IPP } & & $-0.237^{* *}$ & & $-0.213^{*}$ & & $-0.393^{* * *}$ & & $-0.687^{* * * *}$ \\
\hline & & $(0.119)$ & & $(0.117)$ & & $(0.149)$ & & $\begin{array}{l}(0.175) \\
\end{array}$ \\
\hline \multirow[t]{2}{*}{ NEKRETNINE } & & & & & $-0.606^{* *}$ & $-0.704^{* *}$ & $-1.215^{* * * *}$ & $-1.321^{* * *}$ \\
\hline & & & & & $(0.279)$ & $(0.286)$ & $(0.356)$ & $(0.356)$ \\
\hline$N$ & 351 & 351 & 351 & 351 & 342 & 342 & 342 & 342 \\
\hline Tbar & 39.00000 & 39.00000 & 39.00000 & 39.00000 & 38.00000 & 38.00000 & 38.00000 & 38.00000 \\
\hline Sigma & 0.13152 & 0.13108 & 0.13178 & 0.13143 & 0.13136 & 0.13062 & 0.12995 & 0.12896 \\
\hline \multicolumn{9}{|c|}{ Arellano-Bond inicijalni procjenitelj (p-vrijednosti Sarganovog testa i testa autokorelacije 1. i 2. reda) } \\
\hline Sargan & 1.0000 & 1.0000 & 1.0000 & 1.0000 & 1.0000 & 1.0000 & 1.0000 & 1.0000 \\
\hline$m 1$ & 0.0000 & 0.0000 & 0.0000 & 0.0000 & 0.0000 & 0.0000 & 0.0000 & 0.0000 \\
\hline$m 2$ & 0.9750 & 0.9953 & 0.7898 & 0.6864 & 0.8279 & 0.9319 & 0.7850 & 0.3973 \\
\hline
\end{tabular}

Standardne greške u zagradama

${ }^{*} p<0.1,{ }^{* *} p<0.05,{ }^{* * *} p<0.01$

Izvor: prikaz autora 
Modelima 1-8 su prikazani rezultati dobiveni korištenjem pokazatelja ekonomske aktivnosti (indeks industrijske proizvodnje i realni BDP), inflacije, kamatnih stopa, indeksa sentimenta (ESI i indeks pouzdanja potrošača) i indeksa cijena nekretnina kao nezavisnih varijabli. Uvođenjem indeksa cijena nekretnina (modeli 5-8) neke varijable koje u modelima koji ne uključuju cijene nekretnina nisu bile statistički značajne, postaju statistički značajne.

Tablica 3:

\section{REZULTATI MODELA 9-12}

\begin{tabular}{|c|c|c|c|c|}
\hline & $\begin{array}{c}\text { Model } \\
9\end{array}$ & $\begin{array}{c}\text { Model } \\
10\end{array}$ & $\begin{array}{c}\text { Model } \\
11\end{array}$ & $\begin{array}{c}\text { Model } \\
12\end{array}$ \\
\hline \multirow[t]{2}{*}{ L.Cijena } & $0.962^{* * * *}$ & $0.961^{* * * *}$ & $0.965^{* * *}$ & $0.960^{* * * *}$ \\
\hline & $(0.0270)$ & $(0.0271)$ & $(0.0267)$ & $(0.0260)$ \\
\hline \multirow[t]{2}{*}{ IIP } & $0.411^{* *}$ & & $0.762^{* * * *}$ & \\
\hline & $(0.201)$ & & $(0.239)$ & \\
\hline \multirow[t]{2}{*}{ RBDP } & & $0.442^{* *}$ & & $1.278^{* * * *}$ \\
\hline & & $(0.222)$ & & $(0.302)$ \\
\hline \multirow[t]{2}{*}{ IPC } & $1.382^{* *}$ & $1.117^{* *}$ & $2.655^{* * * *}$ & $2.969^{* * * *}$ \\
\hline & $(0.608)$ & $(0.562)$ & $(0.728)$ & $(0.685)$ \\
\hline \multirow[t]{2}{*}{ DOD } & $-0.248^{* * *}$ & $-0.243^{* * *}$ & $-0.587^{* * *}$ & $-0.811^{* * *}$ \\
\hline & $(0.0897)$ & $(0.0899)$ & $(0.147)$ & $(0.164)$ \\
\hline \multirow[t]{2}{*}{ NEKRETNINE } & & & $-0.936^{* * *}$ & $-1.526^{* * * *}$ \\
\hline & & & $(0.343)$ & $(0.393)$ \\
\hline$N$ & 342 & 342 & 342 & 342 \\
\hline $\begin{array}{l}\text { Tbar } \\
\text { Sigma }\end{array}$ & $\begin{array}{c}38.00000 \\
0.13240\end{array}$ & $\begin{array}{c}38.00000 \\
0.13240\end{array}$ & $\begin{array}{c}38.00000 \\
0.13093\end{array}$ & $\begin{array}{c}38.00000 \\
0.12949\end{array}$ \\
\hline \multicolumn{5}{|c|}{$\begin{array}{c}\text { Arellano-Bond inicijalni procjenitelj } \\
\text { (p-vrijednosti Sarganovog testa i testa autokorelacije 1. i 2. reda) }\end{array}$} \\
\hline Sargan & 1.0000 & 1.0000 & 1.0000 & 1.0000 \\
\hline$m 1$ & 0.0000 & 0.0000 & 0.0000 & 0.0000 \\
\hline$m 2$ & 0.9726 & 0.8454 & 0.8141 & 0.8244 \\
\hline
\end{tabular}

Izvor: prikaz autora

Standardne greške u zagradama

$* \mathrm{p}<0.1, * * \mathrm{p}<0.05, * * * \mathrm{p}<0.01$ 
Uključivanjem nove varijable u modelima 9-12 pokazuje se kako rast duga opće države statistički značajno i negativno utječe na cijene dionica u Hrvatskoj. Ostale korištene varijable (indeks industrijske proizvodnje, realni BDP, inflacija te indeks cijena nekretnina) imaju sličan utjecaj kao i u procijenjenim modelima 1-8.

\section{Tablica 4:}

REZULTATI MODELA 13-16

\begin{tabular}{|c|c|c|c|c|}
\hline & $\begin{array}{c}\text { Model } \\
13\end{array}$ & $\begin{array}{c}\text { Model } \\
14\end{array}$ & $\begin{array}{c}\text { Model } \\
15\end{array}$ & $\begin{array}{c}\text { Model } \\
16\end{array}$ \\
\hline \multirow[t]{2}{*}{ L.Cijena } & $0.966^{* * * *}$ & $0.967^{* * * *}$ & $0.969^{\text {***** }}$ & $0.967^{\text {**** }}$ \\
\hline & $(0.0266)$ & $(0.0268)$ & $(0.0268)$ & $(0.0270)$ \\
\hline \multirow[t]{2}{*}{ IIP } & 0.265 & & $0.433^{* *}$ & \\
\hline & $(0.194)$ & & $(0.212)$ & \\
\hline \multirow[t]{2}{*}{ RBDP } & & 0.197 & & $0.582^{* *}$ \\
\hline & & $(0.198)$ & & $(0.252)$ \\
\hline \multirow[t]{2}{*}{ IPC } & 0.712 & 0.525 & $1.591^{* * * *}$ & $1.439^{* *}$ \\
\hline & $(0.510)$ & $(0.479)$ & $(0.598)$ & $(0.571)$ \\
\hline \multirow[t]{2}{*}{ ZIBOR3mj } & $0.0113^{*}$ & 0.0106 & 0.00943 & 0.00904 \\
\hline & $(0.00676)$ & $(0.00670)$ & $(0.00729)$ & $(0.00722)$ \\
\hline \multirow[t]{2}{*}{ NETO ŠTEDNJA } & -0.0238 & -0.0241 & $-0.120^{* * *}$ & $-0.137^{* * * *}$ \\
\hline & $(0.0308)$ & $(0.0313)$ & $(0.0473)$ & $(0.0479)$ \\
\hline \multirow[t]{2}{*}{ NEKRETNINE } & & & $-0.838^{* *}$ & $-1.029^{* * *}$ \\
\hline & & & $(0.328)$ & $(0.349)$ \\
\hline$N$ & 351 & 351 & 342 & 342 \\
\hline Tbar & 39.00000 & 39.00000 & 38.00000 & 38.00000 \\
\hline Sigma & 0.13167 & 0.13184 & 0.13090 & 0.13046 \\
\hline \multicolumn{5}{|c|}{ Arellano-Bond inicijalni procjenitelj } \\
\hline Sargan & 1.0000 & 1.0000 & 1.0000 & 1.0000 \\
\hline$m 1$ & 0.0000 & 0.0000 & 0.0000 & 0.0000 \\
\hline$m 2$ & 0.8844 & 0.7631 & 0.9301 & 0.6907 \\
\hline
\end{tabular}

Izvor: prikaz autora

Standardne greške u zagradama

${ }^{*} p<0.1,{ }^{* *} p<0.05,{ }^{* * *} p<0.01$ 
Rezultati prikazani u Tablici 4 pokazuju kako novouvedena varijabla koja se odnosi na neto štednju sektora kućanstva negativno i statistički značajno utječe na cijene dionica dok je utjecaj ostalih korištenih varijabli sličan kao i kod prethodno procijenjenih modela.

Za sve procijenjene modele su u dnu svake od tablica s rezultatima prikazani rezultati Sarganovog testa te testa autokorelacije prvog i drugog reda koji su dobiveni korištenjem inicijalnog Arellano-Bondovog procjenitelja. Rezultati sugeriraju kako ni u jednom modelu ne postoji problem endogenosti te kako postoji autokorelacija prvog reda, a ne postoji autokorelacija drugog reda. Uključivanje zavisne varijable s jednim vremenskim pomakom a priori ublažava ili, pak, uklanja probleme endogenosti i autokoreliranosti što je prednost dinamičkih panel-modela. U konkretnom slučaju primjene korigiranog procjenitelja fiksnog efekta, rezultate Sarganovog testa i testa autokorelacije prvog i drugog reda treba uzeti s oprezom zbog toga što u sklopu $x t l s d v c$ naredbe u STATI-ju procijenjeni AB model koristi broj instrumenata koji premašuje broj jedinica promatranja, a u takvim situacijama Sarganov test vrlo rijetko odbacuje nultu hipotezu o valjanosti instrumentalnih varijabli. Također, nije svojstveno da je problem autokorelacije prvog reda dalje prisutan i nakon uključivanja lagirane zavisne varijable dok istovremeno ne postoji problem autokorelacije drugog reda. To je dodatni razlog zašto navedene dijagnostičke testove inicijalnog Arellano-Bondovog procjenitelja treba uzeti s rezervom, iako je načelno Sarganov test zadovoljavajući kao i test autokorelacija drugog reda jer se u obama slučajevima nulta hipoteza odbacuje.

Rezultati svih procijenjenih modela (modeli 1-16) pokazuju kako na cijene dionica na hrvatskom tržištu kapitala statistički značajan i pozitivan utjecaj imaju cijene dionica iz prethodnog kvartala, indeks industrijske proizvodnje, realni BDP, inflacija i kamatne stope. S druge strane, negativan utjecaj imaju indeks pouzdanja potrošača, ESI, indeks cijena nekretnina, neto štednja sektora kućanstva te dug opće države.

Pozitivan predznak uz pokazatelje indeksa industrijske proizvodnje i realnog BDP-a teorijski je očekivan. Učinak inflacije na tržišta kapitala uglavnom je negativan, no postoje istraživanja koja su pokazala pozitivnu vezu. Inflacija i inflacijska očekivanja povećavaju diskontnu stopu i smanjuju sadašnju vrijednost budućih novčanih tijekova, a samim tim i cijenu dionice. Barbić i Čondić Jurkić (2017) i Maysami i sur. (2004) su u svojim istraživanjima dokazali postojanje pozitivne veze između kretanja na tržištu kapitala i inflacije. Naime, u slučaju prijetnje inflacije, investitori mogu povećati vlasnička ulaganja kako bi se zaštitili od inflacijskih rizika. Negativna veza između inflacije i cijena dionica može se objasniti i zbog deflacije koja je zabilježena u dijelu razdoblja (od početka 2014. godine do trećeg kvartala u 2016. godini) obuhvaćenog ovim istraživanjem. U tom slučaju opći pad cijena u gospodarstvu ima negativan efekt po poduzeća jer se 
susreću s usporavanjem rasta ili padom prihoda. Stagnacijom ili padom prihoda, valuacije poduzeća postaju lošije te u konačnici dolazi do pada cijena njihovih dionica. Teorijski očekivani utjecaj kamatnih stopa na cijene na tržištu kapitala je jednoznačan i negativan. Rezultati dobiveni ovim istraživanjem pokazuju kako rast 3-mjesečnog ZIBOR-a pozitivno djeluje na cijene dionica, no vrijednosti procijenjenih koeficijenata su izrazito malene (kreću se u rasponu od 0,0111 do 0,0294). Nadalje, rezultati pokazuju kako porastom ESI-ja ili indeksa pouzdanja potrošača, cijene dionica na hrvatskom tržištu kapitala padaju. Ovakvi rezultati nisu u skladu s teorijskim očekivanjem. Za očekivati je bilo da će rastom pozitivnih očekivanja o budućnosti ekonomije, porasti potražnja za proizvodima ili uslugama poduzeća što bi se trebalo pozitivno odraziti na cijenama njihovih dionica. Brown i Cliff (2005), Schmeling (2009), Grigaliūnienè i Cibulskienè (2010), Fisher i Statman (2003) istražuju vezu između dioničkih prinosa i indeksa sentimenta kroz kontekst bihevioralnih financija. Naime, u slučaju pretjeranog optimizma (pesimizma) cijene dionica kreću se na razini višoj (nižoj) od svoje intrinzične vrijednosti, stoga bi razdoblja visokog (niskog) sentimenta trebala biti praćena nižim (višim) prinosima jer će se cijene kroz određeno vremensko razdoblje vratiti svojim fundamentalnim vrijednostima. U svojim istraživanjima su navedeni autori koristili indeks pouzdanja potrošača (Fisher i Statman, 2003; Schmeling, 2009) te ESI (Grigaliūnienė i Cibulskiené, 2010) i pokazali su kako rast vrijednosti indeksa sentimenta u tekućem razdoblju negativno utječe na buduće prinose dionica. Ipak, pozitivan predznak uz ESI i indeks pouzdanja potrošača teško je objasniti na ovaj način iz dvaju razloga. U istraživanju nije korištena varijabla sentimenta s vremenskim pomakom. Također, teško je očekivati da je investitore na hrvatskom tržištu kapitala zahvatilo iracionalno ponašanje povezano s vrijednošću pokazatelja sentimenta jer je hrvatsko gospodarstvo u jednom dijelu promatranog razdoblja bilo u recesiji, a drugim dijelom se oporavljalo i započelo s periodom rasta. Pozitivna veza između indeksa sentimenta i cijena dionica može se racionalnije objasniti u kontekstu neefikasnosti hrvatskog tržišta kapitala. Negativna veza između duga opće države i cijena dionica može se objasniti kroz efekt istiskivanja. Jedan od načina na koji se može nadoknaditi manjak prihoda opće države je izdavanje državnih obveznica. U situaciji izgubljenog povjerenja u tržište kapitala, rast ponude sigurnijih vrijednosnih papira može istisnuti ulaganje u vlasništvo poduzeća. 
Slika 5:

OBVEZNICE RH IZDANE NA HRVATSKOM TRŽIŠTU KAPITALA

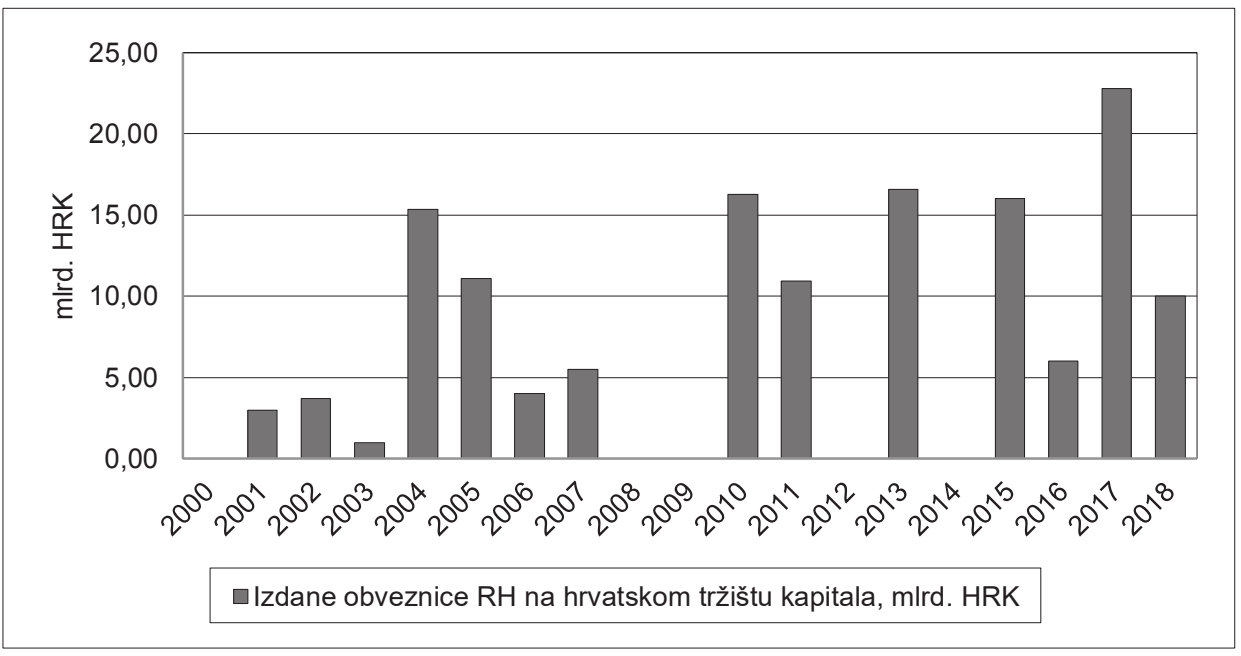

Izvor: prikaz autora prema podacima Ministarstva financija dostupnim na http://www.mfin.hr/hr/ obveznice-domace

Na Slici 5 prikazane su izdane obveznice Republike Hrvatske na domaćem tržištu kapitala. Izdane obveznice u eurima preračunate su u kune prema godišnjim prosjecima srednjih deviznih tečajeva HNB-a u godini izdanja obveznice. Vidljivo je kako je u periodu obuhvaćenom istraživanjem (od 2009. godine do 2018. godine) došlo do značajnijih izdanja obveznica na domaćem tržištu kapitala. Upravo u 2010., 2013., 2015. i 2017. godini su zabilježene najviše vrijednosti izdanih obveznica. Negativna veza na relaciji cijene dionica - indeksa cijena nekretnina i cijene dionica - neto štednje sektora kućanstva također se može objasniti. Između ulaganja u dionice, ulaganja u nekretnine i štednje u banci može postojati konkurencija jer sve varijable zahvaćaju višak sredstava nad potrošnjom. Čuvanjem viška sredstava u obliku štednje i rastom deponiranog novca u bankama, manje će novca ostati na raspolaganju za ulaganja na tržištu kapitala (direktno ili posredstvom fondova) ili ulaganja u nekretnine. U obratnoj situaciji potrage za višim prinosima, novac na štednim računima može se smanjiti i preliti u ulaganja u nekretnine ili u dionice. Dakle, rast potražnje za jednom investicijskom alternativom može biti popraćen padom potražnje za drugim investicijskim alternativama čime se može objasniti negativan predznak između promatranih varijabli. U ovom slučaju, negativni predznak uz varijablu neto štednje sektora kućanstva može značiti kako su 
građani ulaganje u hrvatske dionice percipirali rizičnim te su se odlučili za sigurniju alternativu u vidu deponiranja novca u banku. Negativna veza između cijena dionica i neto štednje sektora kućanstva nije neobična ukoliko se u obzir uzmu kretanja na hrvatskom tržištu kapitala tijekom 2007. i 2008. godine. U konačnici, pokazalo se kako rast cijena nekretnina također negativno utječe na cijene dionica na hrvatskom tržištu kapitala jer te dvije investicijske alternative mogu konkurirati jedna drugoj. Negativan predznak nije neočekivan jer nekretnine imaju značajan udio u imovini hrvatskih građana. Podatci Eurostata prikazani na Slici 6 pokazuju kako u usporedbi s prosjekom Europske unije, Hrvati više preferiraju vlasništvo nad nekretninama. Prosjek EU kreće se na razini od 70\% dok u Hrvatskoj 90\% populacije posjeduje vlasništvo nad nekretninama.

\section{Slika 6:}

\section{DISTRIBUCIJA POPULACIJE S VLASNIŠTVOM NAD NEKRETNINAMA}

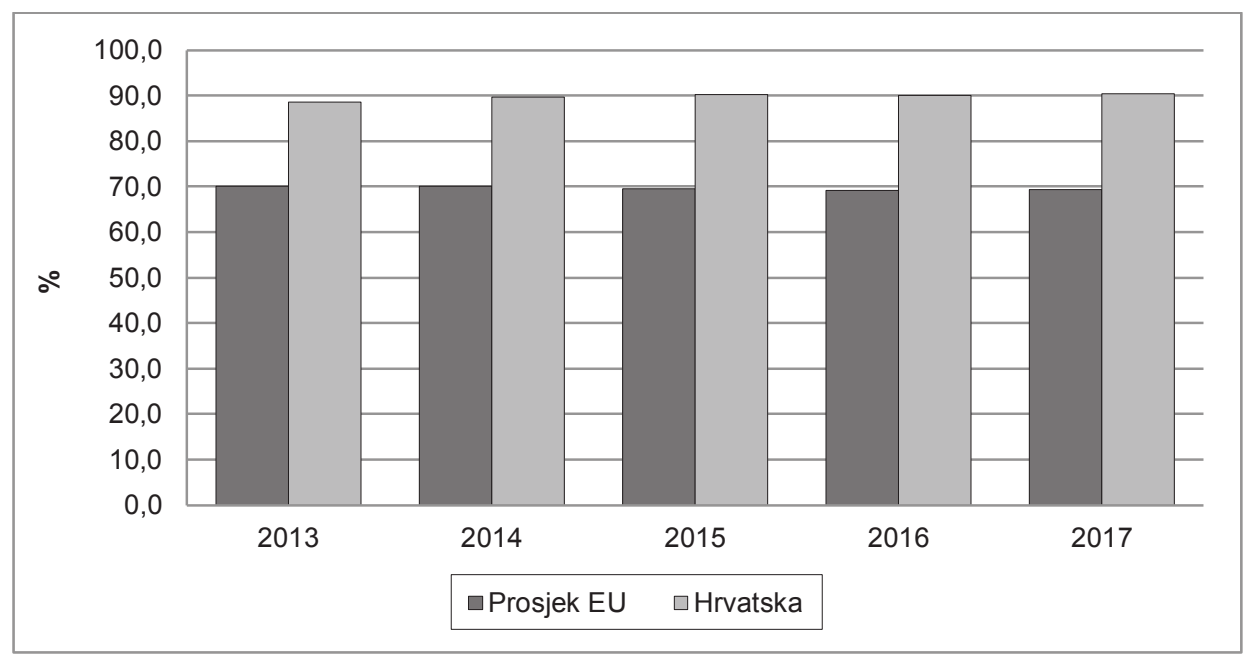

Izvor: Eurostat

\section{ZAKLJUČAK}

Cijene dionica kreću se u ovisnosti o velikom broju faktora. Autori koji su istraživali odnos između makroekonomskih indikatora jednog gospodarstva i cijena dionica svoje su radove temeljili na arbitražnoj teoriji određivanja cijena ili su 
istraživali informacijsku efikasnost tržišta kapitala. U svojim istraživanjima koristili su različite ekonometrijske tehnike (regresijske modele, dinamičke i statičke panel-modele, VAR modele, VEC modele, GARCH modele i dr.) te su najčešće provodili istraživanja na razini burzovnih indeksa ili na razini pokazatelja razvoja tržišta kapitala. Cilj rada bio je istražiti povezanost makroekonomskih indikatora hrvatskog gospodarstva i cijena dionica na domaćem tržištu kapitala. U tu svrhu formiran je dinamički panel-model i korišten korigirani procjenitelj fiksnog efekta. Rezultati procijenjenih modela pokazali su kako na cijene dionica na hrvatskom tržištu kapitala pozitivan utjecaj imaju cijene iz prethodnog razdoblja, indeks industrijske proizvodnje, realni BDP, inflacija i 3-mjesečni ZIBOR. S druge strane, dokazano je da negativan utjecaj na cijene dionica na Zagrebačkoj burzi imaju indeks pouzdanja potrošača, ESI, dug opće države, indeks cijena nekretnina i neto štednja sektora kućanstva. Predznaci uz pokazatelje ekonomske aktivnosti (indeks industrijske proizvodnje i realni BDP) u skladu su s teorijskim očekivanjem. Pozitivan predznak uz indeks potrošačkih cijena djelomično se može opravdati periodom deflacije koji je zahvatio hrvatsko gospodarstvo. Nadalje, pokazalo se kako kamatne stope pozitivno utječu na cijene na hrvatskom tržištu kapitala, no vrijednosti procijenjenih koeficijenata uz 3-mjesečni ZIBOR izrazito su niske (između 0,011 i 0,029). Predznaci uz korištene indekse sentimenta (indeks pouzdanja potrošača i ESI) odudaraju od teorijskog očekivanja što ide u prilog tezama o neefikasnosti hrvatskog tržišta kapitala. Efektom istiskivanja može se objasniti negativan utjecaj rasta duga opće države na cijene dionica na Zagrebačkoj burzi. Za negativan predznak uz indeks cijena nekretnina i neto štednju sektora kućanstva također se može pronaći objašnjenje. Ukoliko se ulaganje u dionice, ulaganje u nekretnine i deponiranje novca u obliku štednje u banci promatraju kao investicijske alternative, tada negativan odnos između parova varijabli cijene dionica - cijene nekretnina i cijene dionica - neto štednja sektora kućanstva može biti očekivan jer ulaganje u jednu alternativu znači da novac neće biti usmjeren u drugu investicijsku alternativu.

\section{LITERATURA}

1. Arellano, M., \& Bond, S. (1991). Some tests of specification for panel data: Monte Carlo evidence and an application to employment equations. The Review of Economic Studies, Vol. 58, No. 2, 277-297. https://doi. org/10.2307/2297968

2. Arouri, M. E., \& Rault, C. (2012). Oil Prices and Stock Markets in GCC Countries: Empirical Evidence from Panel Analysis. International Journal of Finance and Economics, Vol. 17, No. 3, 242-253. https://doi.org/10.1002/ ijfe. 443 
J. ARNERIĆ, L. VLADOVIĆ: Makroekonomske determinante dioničkih cijena na primjeru Hrvatske EKONOMSKI PREGLED, 72 (2) 199-223 (2021)

3. Assefa, T. A., Esqueda, O. A., \& Mollick, A. (2017). Stock returns and interest rates around the World: A panel data approach. Journal of Economics and Business, Vol. 89, 20-35. https://doi.org/10.1016/j.jeconbus.2016.10.001

4. Barbić, T., \& Čondić Jurkić, I. (2017). Do fiscal variables affect stock market returns in EU countries? Ekonomski pregled, Vol.68 No. 3, 253-266. https:// hrcak.srce.hr/184588

5. Barbić, T., \& Čondić-Jurkić, I. (2011). Relationship between macroeconomic fundamentals and stock market indices in selected CEE countries. Ekonomski pregled, Vol. 62 No. 3-4, 113-133. https://hrcak.srce.hr/67210

6. Benaković, D., \& Posedel, P. (2010). Do macroeconomic factors matter for stock returns? Evidence from estimating a multifactor model on the Croatian market? Business Systems Research: International journal of the Society for Advancing Innovation and Research in Economy, Vol. 1 No. 1-2, 39-46. https://doi.org/10.2478/v10305-012-0023-z

7. Billmeier, A., \& Massa, I. (2009). What drives stock market development in emerging markets - institutions, remittances, or natural resources? Emerging Markets Review, Vol. 10, No. 1, 23-35. https://doi.org/10.1016/j.ememar.2008.10.005

8. Blundell, R., \& Bond, S. (1998). Initial conditions and moment restrictions in dynamic panel data models. Journal of Econometrics, Vol.87, 115-143. https://doi.org/10.1016/S0304-4076(98)00009-8

9. Brown, G. W., \& Cliff, M. T. (2005). Investor Sentiment and Asset Valuation. The Journal of Business, Vol. 78, No. 2, 405-440. https://doi. org/10.1086/427633

10. Bruno, G. S. (2005). Approximating the bias of the LSDV estimator for dynamic unbalanced panel data models. Economics Letters, Vol. 87, No. 3, 361366. https://doi.org/10.1016/j.econlet.2005.01.005

11. Chen, N. F., Roll, R., \& Ross, S. A. (1986). Economic Forces and the Stock Market. The Journal of Business, Vol. 59 No. 3, 383-402. https://doi. org/10.1086/296344

12. Fisher, K. L., \& Statman, M. (2003). Consumer Confidence and Stock Returns. The Journal of Portfolio Management, Vol. 30, 115-127. https://doi. org/10.3905/jpm.2003.319925

13. Grigaliūnienè, Ž., \& Cibulskienè, D. (2010). Investor Sentiment Effect on Stock Returns in Scandinavian Stock Market. Economics and Management, Vol. 15, 929-940.

14. Hsing, Y. (2011). Macroeconomic variables and the stock market: The case of Croatia. Economic research - Ekonomska istraživanja, Vol. 24, No. 4, 41-50. https://doi.org/10.1080/1331677X.2011.11517479 
15. Humpe, A., \& Macmillan, P. (2009). Can macroeconomic variables explain long-term stock market movements? A comparasion of the US and Japan. Applied Financijal Economics, Vol. 19, No. 2 111-119. https://doi. org/10.1080/09603100701748956

16. Jamaludin, N., Ismail, S., \& Manaf, S. A. (2017). Macroeconomic Variables and Stock Market Returns: Panel Analysis from Selected ASEAN Countries. International Journal of Economics and Financial Issues, Vol. 7, No 1, 37-45.

17. Maysami, R. C., Howe, L. C., \& Hamzah, M. A. (2004). Relationship between Macroeconomic Variables and Stock Market Indices: Cointegration Evidence from Stock Exchange of Singapore's All-S Sector Indices. Jurnal Pengurusan, Vol. 24, 47-77. https://doi.org/10.17576/pengurusan-2005-24-03

18. Mbanga, C. L., \& Darrat, A. F. (2016). Fiscal policy and the US stock market. Review of Quantitative Finance and Accounting, Vol. 47, No. 4, 987-1002. https://doi.org/10.1007/s11156-015-0528-y

19. Mensi, W., Hammoudeh, S., Yoon, S.-M., \& Balcilar, M. (2016). Impact of macroeconomic factors and country risk ratings on GCC stock markets: evidence from a dynamic panel threshold model with regime switching. Applied Economics, Vol.49, No. 13, 1255-1272. https://doi.org/10.1080/00036846.201 6.1217305

20. Olgić Draženović, B., \& Kusanović, T. (2016). Determinants of capital market in the new member EU countries. Economic Research-Ekonomska istraživanja, Vol. 29, 758-769. https://doi.org/10.1080/1331677X.2016.1197551

21. Pradhan, R. P., Arvin, M. B., Hall, J. H., \& Bahmani, S. (2014). Causal nexus between economic growth, banking sector development, stock market development, and other macroeconomic variables: The case of ASEAN countries. Review of Financial Economics, Vol. 23, No. 4, 155-173. https://doi. org/10.1016/j.rfe.2014.07.002

22. Radman Peša, A., \& Festić, M. (2014). Panel regression of stock market indices dynamics in south-eastern European countries. Economic ResearchEkonomska istraživanja, Vol.27, No. 1, 673-688. https://doi.org/10.1080/1331 677X.2014.975515

23. Ratanapakorn, O., \& Sharma, S. C. (2007). Dynamic analysis between the US stock returns and the macroeconomic variables. Applied Financial Economics, Vol. 17, No. 5, 369-377. https://doi.org/10.1080/09603100600638944

24. Schmeling, M. (2009). Investor sentiment and stock returns: Some international evidence. Journal of Empirical Finance, Vol. 16, No. 3, 394-408. https:// doi.org/10.1016/j.jempfin.2009.01.002

25. Subeniotis, D. N., Papadopoulos, D. L., Tampakoudis, I. A., \& Tampakoudi, A. (2011). How Inflation, Market Capitalization, Industrial Production and 
the Economic Sentiment Indicator Affect the EU-12 Stock Markets. European Research Studies, Vol. XIV, No 1, 103-118.

26. Şükrüoğlu, D., \& Nalin, H. T. (2014). The Macroeconomic Determinants of Stock Market Development in Selected European Countries: Dynamic Panel Data Analysis. International Journal of Economics and Finance, Vol. 6, No. 3, 64-71. https://doi.org/10.5539/ijef.v6n3p64

27. Škrabić Perić, B. (2019). Do the most frequently used dynamic panel dana estimators have the best performance in a small sample? A Monte Carlo comparison. Croatian Operational Research Review, Vol. 10, No. 1, 45-54. https://doi.org/10.17535/crorr.2019.0005

28. Yartey, C. A. (2010). The institutional and macroeconomic determinants of stock market development in emerging countries. Applied Financial Economics, Volume 20 Issue 21, 1615-1625. https://doi.org/10.1080/09603107.2010. 522519

\title{
MACROECONOMIC DETERMINANTS OF STOCK PRICES, EVIDENCE FROM CROATIA
}

Summary

\begin{abstract}
This paper aims to explore dependence between macroeconomic indicators of the Croatian economy and stock prices on the Zagreb Stock Exchange. Panel data and Least Squares Dummy Variable Corrected estimator (LSDVc) was used for that purpose. In the previous studies on this topic, an LSDVc estimator was not used, but other estimators where employed for static panel models (fixed-effect estimator and pooled OLS estimator) and dynamic panel models (ArellanoBond estimator and Blundell-Bond estimator). Therefore, the use of LSDVc estimator is the major contribution of this paper. The results of the estimated dynamic panel models showed that stock prices from the previous quarter, the index of industrial production, real GDP, inflation and interest rates have a statistically significant and positive impact on stock prices on the Croatian capital market. On the other hand, consumer confidence index, Economic sentiment indicator, house price index, household net savings and general government debt have a negative impact on stock prices.
\end{abstract}

Key words: dynamic panel model, LSDVc estimator, capital market, macroeconomic indicators 